\title{
Особливості гемодинаміки представників ациклічних видів легкої атлетики з прегіпертензією в різні періоди річного макроциклу
}

\author{
Юрій Атаман, Ірина Бріжата, Олександр Атаман, \\ Ірина Симоненко
}

\author{
Сумський державний університет, Суми, Україна
}

Анотація. Актуальність дослідження зумовлена невирішеністю питання вчасного виявлення та корекції вегетативної дисфункції у спортсменів-професіоналів, особливо у тих, у яких наявні передпатологічні стани. Вивчення прихованих змін гемодинаміки разом із вчасним виявленням дизавтономних проявів у спортсменів з прегіпертензією (ПГ), особливо у тих, хто займається переважно силовими вправами, є перспективним напрямом покращення здоров'я та успішності. Мета. Вивчення гемодинамічного профілю представників ациклічних видів легкої атлетики з офрісною ПГ у різні періоди річного макроциклу. Методи. Аналіз науково-методичної літератури, анкетування за Вейном; контроль артеріального тиску; методи математичної статистики. Результати. Встановлено, що для спортсменів 3 ПГ найбільш несприятливим виявився змагальний період, в якому були найбільш поширеними та вираженими симптоми вегетативної диссункції, значно переважали середні значення артеріального тиску, поширеність та ймовірність розвитку замаскованої артеріальної гіпертензії.

Змагальний період річного макроциклу у представників ациклічних видів легкої атлетики з прегіпертензією супроводжується зростанням значень артеріального тиску, при цьому відносний ризик прихованої артеріальної гіпертензії в позатренувальний час зростає за наявності інших проявів вегетативної дисфуннкції. Зміни не є стійкими, проте їх вчасне виявлення та корекція можуть сприяти покращенню якості життя спортсменів та їх успішності. Ключові слова: артеріальний тиск, автономна диссуункція, змагальний період річного макроциклу.

Yurii Ataman, Iryna Brizhataia, Oleksandr Ataman, Iryna Symonenko

FEATURES OF HEMODYNAMICS IN ATHLETES OF ACYCLIC TRACK-ANDFIELD DISCIPLINES WITH PREHYPERTENSION IN DIFFERENT PERIODS OF THE ANNUAL MACROCYCLE

Summary. The relevance of the study is due to the unresolved issue of timely detection and correction of autonomic dysfunction in professional athletes, especially those with a prepathological condition. The study of latent changes in hemodynamics, together with the timely detection of dysautonomia symptoms in athletes with prehypertension $(\mathrm{PH})$, especially in those who are mainly engaged in strength training, is a promising area for improving health and performance. Objective. To study the features of hemodynamics in athletes of acyclic track-andfield disciplines with office PH in different periods of the annual macrocycle. Methods. Scientific and methodological literature review, Veyn questionnaire survey; blood pressure control;

Ataman Yu., Brizhataia I., Ataman 0.,

Symonenko I. Features of hemodynamics in athletes of acyclic track-and-field disciplines with prehypertension in different periods of the annual macrocycle. Theory and Methods of Physical education and sports. 2021; 3 : 84-88

DOI: 10.32652/tmfvs.2021.3.84-88
Атаман Ю., Бріжата І., Атаман 0., Симоненко І. Особливості гемодинаміки представників ациклічних видів легкої атлетики з прегіпертензією в різні періоди річного макроциклу. Теорія і методика фрізичного виховання і спорту. 2021; 3: 84-88

DOI: 10.32652/tmfvs.2021.3.84-88
Вступ. Згідно з останнім переглядом європейських рекомендацій з виявлення та лікування артеріальної гіпертензії [20], наявність офрісного артеріального тиску (АТ) систолічного у межах $\geq 130$ та $<140$ мм рт. ст. та діастолічного АТ у межах $\geq 85$ та < 90 мм рт. ст. розглядають як високі нормальні значення (прегіпертензія). При цьому передпатологічному стані зростають частота небажаних серцево-судинних подій, зокрема ймовірність стійкої гіпертонічної хвороби [15]. В аспекті спортивної діяльності варто зазначити, що на сьогодні відсутні дані про наявність системної різниці у підходах до предикції та оцінювання ймовірного ризику при підвищенні АТ у спортсменів та інших осіб [7, 17]. Зазначається, що підвищення АТ в атлетів залежить від рівня та характеру фрізичної активності (переважання циклічних/ациклічних вправ), є найбільш частою проблемою під час періодичних оглядів, поширеність прегіпертензії може перевищувати дві третини всіх обстежених. Крім цього, за даними спеціальної літератури, важливим є вплив підвищеного артеріального тиску на швидкість та характер розвитку змін міокарда [11]. Згідно 3 нашими спостереженннями [9], спортсмени 3 прегіпертензією більш уразливі до порушень реполяризації, які ми відмічали на фроні розвитку спортивного серця.

Серед основних причин підвищення АТ у спортсменів можна виділити хронічний стрес, викликаний синдромом перетренованості, та пов'язані 3 ним порушення автономної регуляції, які проявляють себе у пригніченні парасимпатичних впливів та гіперактивації симпатоадреналової систе- 
and methods of mathematical statistics. Results. It was found that the most unfavorable for athletes with GHG was the competitive period, when the most common and pronounced symptoms of autonomic dysfunction were observed, the average blood pressure were significantly exceeded, and the likelihood of masked hypertension increased.

The competitive period of the annual macrocycle was accompanied by an increase in blood pressure in acyclic athletes with prehypertension, while the relative risk of latent hypertension in extracurricular time increased in the presence of other manifestations of autonomic dysfunction. Changes are not persistent, and their timely detection and correction can help improve the quality of life of athletes and their successful performance.

Keywords: blood pressure, autonomic dysfunction, competitive period of the annual macrocycle.

ми [6]. І якщо саму по собі прегіпертензію не розглядають як патологічний стан, то розвиток гіпертензивного стану може мати більш серйозні наслідки, проте діагноз гіпертонічної хвороби має базуватися в тому числі на стійкості виявлених гемодинамічних змін [20]. У наших роботах зазначається, що у спортсменів високого класу необхідний активний скринінг, спрямований на пошук прихованої патології, зокрема з метою оцінювання стану серцево-судинної системи [1, 2]. Якщо вести мову про артеріальну гіпертензію, то слід зазначити, що під час проведення амбулаторного моніторингу АТ встановлено, що у футболістів з нормальними значення АТ вона виявлялася замасковано з частотою 30-50 \% [8].

Відомо, що поширеність замаскованої гіпертензії зростає у молодих фрізично активних людей на фоні стресу та професійної активності, особливо у тих, які мають високі нормальні значення артеріального тиску [20], а серцево-судинний ризик може бути навіть більшим, ніж при стійкій гіпертензії. У згаданих вище рекомендаціях пропонується використовувати амбулаторний або домашній моніторинг АТ (ДМАТ) для виявлення замаскованої гіпертензії. Проте амбулаторний моніторинг має ряд недоліків, які у спортсменів можуть мати важливий вплив на показники. Основні 3 них - це дискомфорт під час проведення тренувань, зміна звичної денної активності та робота пристрою під час сну. ДМАТ позбавлений цих недоліків, оскільки є більш зручним для використання у змінюваних умовах перебування атлетів, дає можливість проводити довготривалі повторні вимірювання протягом дня [19]. Враховуючи поширеність гемодинамічних змін у профресійних спортсменів, особливо з виконанням переважно силових на- вантажень [6], ми поставили за мету вивчення профілю артеріального тиску під час трьох періодів тренувального річного макроциклу, який включає підготовчий, змагальний та перехідний періоди [5, 12]. Кожен з цих періодів характеризується різними фрізичними та емоційними навантаженнями, адаптаційними викликами під час перельотів та частотою розвитку циркадних порушень, характером харчування тощо. Зазначені фактори можуть мати суттєвий вплив на загальний стан спортсменів та показники артеріального тиску.

Мета дослідження - вивчення гемодинамічного профілю представників ациклічних видів легкої атлетики 3 офрісною прегіпертензією у різні періоди річного макроциклу.

Методи дослідження: аналіз науково-методичної літератури; анкетування за Вейном, контроль артеріального тиску; методи математичної статистики.

Результати дослідження таїх обговорення. Двадцять п'ять легкоатлетівпрофесіоналів, а саме представників ациклічних видів (стрибки, метання, штовхання ядра, бар'єрний біг), було включено до дослідження, спостереження за спортсменами проводили на базі центру спортивної медицини Сумського державного університету 3 2017 по 2021 р. Тижнева тренувальна активність усіх обстежених становила понад 8 год протягом останніх 3 місяців до включення в дослідження. Пояснення протоколу та отримання згоди на участь у дослідженні проходило після поглибленого обстеження протягом перших 10 днів підготовчого періоду. Середній вік обстежених -23,04 $(2,84)$ року, кількість осіб жіночої статі шість (24\%), тривалість спортивного анамнезу 9,96 $(2,98)$ року, у шести осіб (24\%) спостерігалися хронічні проблеми опорно-рухового апара- ту, які дозволяли спортсменам займатися тренувально-змагальною діяльністю. Всі учасники надали інформовані згоди на участь у дослідженні та включення наданої особистої інформації до бази даних. Дотримання біоетичних стандартів було розглянуто на комісії з біоетики медичного інституту Сумського державного університету (протокол № 4/5 від 12.05.2021).

Вимірювання АТ проводили в офісі осцилометричним методом з вибором підходящого розміру манжети залежно від окружності плеча згідно зі стандартизованим протоколом 3 вимірювання АТ в оорісі $[14,19]$. Вимірювання АТ вдома здійснювали самостійно двічі на день (після прокидання та у вечірній час, не менше ніж через 2 год після тренувань) протягом трьох-семи днів $(\mathrm{M}=5,6(1,0)$ дня) згідно 3 рекомендаціями 3 домашнього моніторингу артеріального тиску $[18,19]$. Окрім цього, всім спортсменам проводили вимірювання антропометричних показників, здійснювали опитування про скарги, анкетування за опитувальником Вейна [3] та загальне обстеження. Їх проводили протягом року тричі: у підготовчому, змагальному та відновлювальному періодах річного макроциклу. Річна тривалість підготовчого періоду - 232,6 $(16,8)$ дня, змагального - 65,2 $(6,5)$ дня, відновлювального (включно 3 незапланованими періодами) - 67,0 $(6,8)$ дня.

Статистичний аналіз проводили за допомогою відкритого вебресурсу socscistatistics.com 3 дотриманням рекомендацій до використання статистичних методів у медицині [4]. Середні величини подано у формі M (SD), де M - середнє арифметичне, SD - стандартне відхилення. Дискретні змінні були представлені у вигляді відсотків, їх порівняння здійснювали за допомогою розрахунку критерію $\chi 2$ з виконанням корекції за Yates [10]. Порівняння середніх величин у різних періодах річного макроциклу проводили за допомогою методу ANOVA для повторних вимірювань, частотних показників - розрахунку критерію $\chi 2$. Для розрахунку ймовірності розвитку симптомів розраховували показник відносного ризику (RR), під час аналізу асоціації цих фракторів з рівнем АТ також вико- 
Т а б л и ц я 1. Динаміка антропометричних показників, особливостей тренувальної активності та наявність симптомів протягом річного макроциклу

\begin{tabular}{|c|c|c|c|c|}
\hline \multirow{2}{*}{ Показник } & \multicolumn{3}{|c|}{ Період } & \multirow{2}{*}{$\mathbf{p}$} \\
\hline & підготовчий & змагальний & перехідний & \\
\hline їндекс маси тіла, кг/м² & $24,3(5,12)$ & $23,01(4,44)$ & $24,31(4,57)$ & $<0,001$ \\
\hline \% жирової тканини & $15,94(3,25)$ & $15,47(3,89)$ & $19,53(5,0)$ & 0,003 \\
\hline Середньотижневий тренувальний час, г & $18,32(2,85)$ & $15,61(3,11)$ & $12,21(3,96)$ & $<0,001$ \\
\hline Слабкість, що триває щонайменше два тижні, \% & $2(8)$ & $11(44)$ & $3(12)$ & 0,003 \\
\hline Порушення сну, \% & $5(20)$ & $10(40)$ & $2(8)$ & 0,024 \\
\hline $\begin{array}{l}\text { Збільшення зусилля для виконання стандартного наван- } \\
\text { таження, \% }\end{array}$ & $9(36)$ & $15(60)$ & $2(8)$ & $<0,001$ \\
\hline Підвищена чутливість до холоду та спеки, \% & $5(20)$ & $8(32)$ & $3(12)$ & 0,221 \\
\hline Наявність інших симптомів вегетативної дисфункції, \% & $5(20)$ & $8(32)$ & $3(12)$ & 0,221 \\
\hline Їндкс Вейна, бал & $4,48(5,16)$ & $9,44(6,62)$ & $3,24(3,55)$ & $<0,001$ \\
\hline $\begin{array}{l}\text { Частота серцевих скорочень у спокої під час офісного } \\
\text { контролю, уд. · хв }\end{array}$ & $56,4(10,61)$ & $57,8(9,27)$ & $60,3(9,33)$ & 0,030 \\
\hline
\end{tabular}

ристовували показник відношення шансів (OR). Статистично значущою вважали величину критерію $p<0,05$.

у ході дослідження було встановлено, що для спортсменів 3 прегіпертензією були досить поширеними симптоми хронічного стресу та вегетативної дисфункції (табл. 1). Найчастіше спостерігалися слабкість, порушення сну, зниження толерантності до фрізичного навантаження, а найтяжчим виявився змагальний період, під час якого частота практично всіх симптомів була найвищою $(p<0,05)$. Під час відновлення та відсутності необхідності підтримання спортивної форми симптоматика покращувалася навіть порівняно 3 підготовчим періодом. Порушення сну у перехідному періоді встановлено лише у двох осіб (8\%), порівняно 3 п'ятьма (20 \%) атлетами у підготовчому періоді. Виявлені закономірності підтверджуються розрахунком індексу Вейна (інтегративним показником наявності вегетативної дисфрункції), який набув найбільших значень у спортсменів у змагальному періоді і становив 9,44 $(6,62)$ бала.

Під час порівняння середніх значень офрісного та максимального домашнього АТ було встановлено значне переважання рівня як систолічного, так і діастолічного АТ в змагально- му періоді ( $p<0,001)$, наступним за середнім значенням АТ був підготовчий період (табл. 2).

У ході порівняння частотних показників встановлено, що у змагальному періоді також переважала поширеність замаскованої артеріальної гіпертензії, тобто такої, що реєструється лише під час домашніх вимірювань. Так, частота систолічної артеріальної гіпертензії у трьох послідовних періодах становила 16,48 та $8 \%\left(\chi^{2}=12,28 ; p=0,002\right)$, діастолічної - 16, 36 та 4 \% відповідно $(\chi 2=6,5 ; p=0,039)$. Лише у двох випадках (8 \%) вона мала ізольований систолічний характер та з більшою ймовірністю могла б бути зумовлена проблемами вимірювання. Нами також було розраховано відносний ризик (RR) та показник відношення шансів (OR) появи при- хованої артеріальної гіпертензії у представників ациклічних видів легкої атлетики прегіпертензією залежно від наявності вегетативної диссрункції (рис. 1).

Суттєвим чином ймовірність підвищення АТ вище нормальних значень у спортсменів з симптомами порушення автономної регуляції зростала в змагальному періоді $(R R=3,25$; $\mathrm{OR}=10,0 ; p=0,027)$, проте у підготовчому та перехідному періодах вірогідність появи артеріальної гіпертензії за таких умов залишалася поза межами статистичної значущості ( $p>0,05)$.

Відомо, що для ациклічних видів спортивної діяльності характерним $€$ виконання роботи змінної інтенсивності з переважно анаеробним енергозабезпеченням під час виконання максимального фрізичного навантажен-

Т а б л и ц я 2. Офісний та домашній артеріальний тиск на різних етапах підготовки спортсменів

\begin{tabular}{|l|c|c|c|c|}
\hline \multirow{2}{*}{\multicolumn{1}{|c|}{ АТ, мм рт. ст. }} & \multicolumn{3}{|c|}{ Період } & \multirow{2}{*}{ p } \\
\cline { 2 - 4 } & підготовчий & змагальний & перехідний & \\
\hline Офісний систолічний & $134,8(3,43)$ & $136,2(3,04)$ & $129,2(7,05)$ & $<0,001$ \\
\hline Домашній систолічний & $\begin{array}{c}136,12 \\
(7,13)\end{array}$ & $\begin{array}{c}141,52 \\
(9,95)\end{array}$ & $130,7(8,13)$ & $<0,001$ \\
\hline Офісний діастолічний & $83,32(4,76)$ & $85,72(3,08)$ & $79,16(4,68)$ & $<0,001$ \\
\hline Домашній діастолічний & $84,8(6,09)$ & $90,68(5,54)$ & $81,24(6,38)$ & $<0,001$ \\
\hline
\end{tabular}


ня. За даними спеціальної літератури, такі спортсмени схильні до розвитку нефункціонального перевантаження та перетренованості - важливих чинників вегетативної дисфункції (дисавтономії) у спортсменів-професіоналів [16]. Окрім постійного перевантаження серед частих несприятливих впливів на організм можна назвати емоційні стреси, зміни кліматогеографічних умов, проблеми поточного відновлення після відповідальних змагань, наслідки перенесених інфекцій тощо. Вплив цих чинників на організм спортсменів протягом року не є однаковим, кожен з періодів річного макроциклу характеризується власними медикобіологічними викликами [5]. Очевидно, що найтяжчих впливів зазнає організм спортсменів під час інтенсивних силових тренувань та відповідальних стартів. Важливим у цьому аспекті є індивідуальний підхід до кожного атлета, виявлення скарг, що можуть бути ранніми ознаками вегетативної дисавтономії, проте останні (наприклад, слабкість, зниження толерантності до фізичного навантаження) інколи важко диференціювати 3 синдромом хронічної втоми, відсутністю психологічної підготовки, мотивації, інших фракторів, що є складовими відсутності очікуваного результату.

Допомога спортивного лікаря орієнтована на виявлення об'єктивних симптомів можливого порушення автономної регуляції. Зокрема, у спортсменів зазначеної групи ці порушення протікають зазвичай у вигляді гіперактивації симпатоадреналової системи з відповідними клінічними проявами [13]. Останні можуть мати невиражений прихований характер, бути передвісниками більш серйозних порушень фрізіологічних фуннцій. Так, наявність у спортсменів високих нормальних значень АТ за умов вимірювання в поліклініці (прегіпертензія) може бути фрізіологічною особливістю індивідуума, проте може бути свідченням дезадаптації, вегетативної дисфункції. Як зазначалося у вступі, прегіпертензія має ознаки передпатологічності та зумовлює передусім ризик розвитку стійкого підвищення АТ вище нормальних значень. Вимірювання та моніторинг АТ у домашніх умовах дає можливість вчасно виявляти гіпертензію, яка часто має за- маскований характер і не була б зареєстрованою за відсутності вимірювань вдома.

Наші дослідження показали, що різні періоди річного макроциклу характеризуються різною частотою та вираженістю (індекс Вейна) проявів вегетативної дисфункції. Зазначене $€$ актуальним для таких симптомів, як слабкість, порушення сну, зниження толерантності до фрізичного навантаження, що спостерігалися з вищою частотою, як і значення інтегративного показника Вейна, в змагальному періоді. Саме в ньому на спортсмена діє цілий комплекс чинників хронічного стресу, які можуть викликати значущі гемодинамічні зміни, зумовлені симпатотонією. У цьому періоді нами було зареєстровано найбільші значення систолічного та діастолічного АТ як під час вимірювання спортивним лікарем, так і самостійно вдома, під час відпочинку. В змагальному періоді також відмічалася висока частота виявлення артеріальної гіпертензії в домашніх умовах у майже кожного другого спортсмена 3 прегіпертензією. При цьому у змагальному періоді середній показник систолічного АТ під час домашнього вимірювання перевищив нормальні значення і становив 141,52 $(9,95)$ мм рт. ст.

Гемодинамічні зміни у змагальному періоді прямо пов'язані з автономною дисрегуляцією, зокрема нами встановлено зростання відносного ризику гіпертензії за наявності дисавтономії у понад 3 рази ( $p=0,027)$. Проте такі зміни є транзиторними, оскільки у перехідному періоді рівень АТ переважної частини учасників дослідження нормалізувався (знизився приблизно на $10 \%$ ), статистично значуще знизилася частота гіпертензії (систолічного АТ з 48 до $8 \%$, діастолічного з 36 до $8 \%$ ), суттєво зменшилася частота серцевих скорочень ( $p=0,030)$, зазначене супроводжувалося значною редукцією проявів вегетативної дисфункції. Таким чином, незважаючи на відсутність стійких змін гемодинаміки у спортсменів-просресіоналів 3 прегіпертензією, ми вважаємо, що вчасне виявлення симптомів автономної дисрегуляції, зокрема у вигляді прихованої артеріальної гіпертензії, сприятиме покращенню якості їхнього життя та успішності.

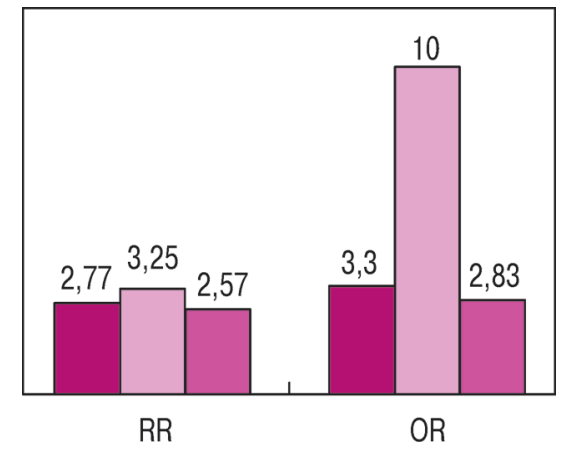

Рисунок 1 - Порівняння відносного ризику та відношення шансів появи прихованої гіпертензії залежно від наявності дисавтономії та періоду макроциклу: період:

$\square$ - підготовчий; $\square$ - змагальний; $\square$ - перехідний

Висновки. Змагальний період річного макроциклу у представників ациклічних видів легкої атлетики з прегіпертензією супроводжується зростанням значень АТ, при цьому відносний ризик прихованої артеріальної гіпертензії в позатренувальний час зростає за наявності інших проявів вегетативної дисфункції. Встановлено, що зазначені зміни не є стійкими, проте їх вчасне виявлення та корекція можуть сприяти покращенню якості життя спортсменів та їх успішності.

Перспективи подальших досліджень передбачають у рамках науково-дослідницької теми центру спортивної медицини Сумського державного університету проведення дослідження 3 раннього виявлення латентних ознак автономної диссрункції спортсменів-легкоатлетів та інших факторів, що впливають на їхнє здоров'я та спортивну результативність.

Конфлікт інтересів. Автори заявляють, що відсутній будь-який конфолікт інтересів.

\section{ЛITEPATУРА}

1. Атаман Ю, Бріжата І, КоржВ, Прийменко Л Волнушкіна Н. Зв'язок даних спортивного анамнезу професійних легкоатлетів зі стійкою прегіпертензією в підготовчому періоді річного макроциклу. Український журнал медицини, біології та спорту. 2020;5(27):371-376.

2. Атаман Ю, Корж В, Гордіна М, Моісеєнко I Радич К. Зв'язок ранньої реполяризації шлуночків з ознаками ремоделювання у професійних спортсменів. Вісник проблем біології та медицини. 2019;2 (150):96-99.

3. Вейн АМ. Вегетативные расстройства. Клиника, діагностика, лечение. Москва: Медицина; 1998.740 с.

4. Голованова IA, Бєлікова IB, Ляхова НО. Основи медичної статистики. Полтава: УМСА; 2017. 113 c. 
5. Платонов ВН. Общая теория подготовОлімпійський спорт; 1997. 583 с.

6. Baumert M, Brechtel L, Lock J, Hermsdorf $M$, Wolff $R$, et al. Heart rate variability, blood pressure variability, and baroreflex sensitivity in overtrained athletes. Clin J Sport Med. 2016 Sep;16(5):412-7. doi: 10.1097/01.jsm 0000244610.34594 .07

7. Berge $H$, Isern C, Berge E. Blood pressure and hypertension in athletes: a systematic review. Br. J. Sports Med. 2015;49 (11): 716-723. doi: 10.1136/bjsports-2014-093976.

8. Berge HM, Andersen T, Solberg E, Steine K. High ambulatory blood pressure in male professional football players. $\mathrm{Br} \mathrm{J}$ Sports Med 2013May;47(8):521-5.doi:10.1136/bjsports-2013092354.

9. Brizhatyi A, Ataman Y, Brizhataia I, Korzh V Zharkova $A$, et al. Ventricular repolarization measures in professional and amateur athletes with high normal arterial pressure. Georgian Med News 2020 Jan;(298):123-128.

10. Haviland M. Yates's correction for continuity and the analysis of $2 \times 2$ contingency tables. Stat Med. 1990 Apr;9(4):363-7; discussion 369-83. doi: 10.1002/sim.4780090403.

11. Hedman K, Moneghetti K, Christle J, Bagherzadeh S, Amsallem M, et al. Blood pressure in athletic preparticipation evaluation and the implication for cardiac remodeling. Heart 2019 Aug;105(16):1223-1230. doi: 10.1136/

12. Garrett W, Kirkendall J, Kirkendall D. Exercise and Sport Science. USA: Walters Kluwer Health; 2000. 500 p.

13. Grandou C., Wallace L, Impellizzeri F, Allen N, Coutts A. Overtraining in Resistance Exercise: An Exploratory Systematic Review and Methodological Appraisal of the Literature. Sports Med. 2020 Apr;50(4):815-828. doi: 10.1007/ s40279-019-01242-2.

14. James G, Gerber L. Measuring arteria blood pressure in humans: Auscultatory and automatic measurement techniques for human biological field studies. Am J Hum Biol. 2018 Jan;30(1) ):421-5. doi: 10.1002/ajhb.23063

15. Kokubo Y, Kamide K. High-normal blood pressure and the risk of cardiovascular disease. ки спортсменов в олимпийском спорте. Киев: heartinl-2019-314815

Circ J. 2009 Aug;73(8):1381-5. doi: 10.1253/circj. cj-09-0336.

16. Kreher J, Schwartz J Overtraining syndrome: a practical guide. Sports Health. 2012 Mar;4(2):128-38. doi: 10.1177/1941738111434406.

17. Pescatello L, Buchner D, Jakicic J, Po well K, Kraus W, et al. Physical Activity to Prevent and Treat Hypertension: A Systematic Review. Med Sci Sports Exerc. 2019 Jun;51(6):1314-1323. doi: 10.1249/MSS.0000000000001943.

18. Stergiou G, Kario K, Kollias A, McManus $\mathrm{R}$, Ohkubo $\mathrm{T}$, et al. Home blood pressure monitoring in the 21 st century. J Clin Hypertens (Greenwich). 2018 Jul;20(7):1116-1121. doi: 10.1111/ jch.13284.

19. Vischer A, Burkard T. Principles of Blood Pressure Measurement - Current Techniques, Office vs Ambulatory Blood Pressure Measurement. Adv Exp Med Biol. 2017;956:85-96. doi 10.1007/5584_2016 49.

20. Williams B, Mancia G, Spiering W, Agabiti Rosei E, Azizi M, et al. 2018 ESC/ESH Guidelines fo the management of arterial hypertension: The Task Force for the management of arterial hypertension of the European Society of Cardiology (ESC) and the European Society of Hypertension (ESH). European Heart Journal. 2018 Sep;39(33):3021-3104. doi: 10.1093/eurheartj/ehy339.

\section{LITERATURE}

1. Ataman Yu, Brizhataia I, Korzh V, Pryimenko L, Volnushkina N. Assotiation between sport anamnesis data of professional athletes and sustained prehypertension during the preparatory period of the annual macrocycle. Ukrainian journa of medicine, biology and sport. 2020;5(27):371376.

2. Ataman Yu, Korzh V, Gordina M, Moiseienko I, Radych K. Relationship between early ventricular repolarization and signs of myocardial remodeling in professional athletes. Bulletin of problems in biology and medicine. 2019:2 (150):96-99.

3. Veyn AM. Autonomic dysfunctions. Clinics diagnosis, and treatment. Moscow: Meditsina; 1998. $740 \mathrm{p}$.

4. Golovanova IA, Bielikova IV, Liakhova NO The fundamentals of medical statistics. Poltava; UMSA; 2017. $113 p$

\section{ІНФОРМАЦІЯ ПРО АВТОРІВ}

Атаман Юрій Олександрович ata_kard@ukr.net, ORCID: 0000-0002-6398-1016

Бріжата Ірина Анатоліївна brizhata@i.ua, ORCID: 0000-0002-9988-4285 Симоненко Ірина Андріївна irinasimonenko.532@gmail.com, ORCID: 0000-0002-8406-5682

Сумський державний університет

40001, м. Суми, вул. Академічна, 9

Атаман Олександр Васильович olex0101@gmail.com, ORCID: 0000-0002-1941-740X Сумський державний університет 40007, м. Суми, вул. Санаторна, 31

\section{INFORMATION ABOUT THE AUTHORS}

Ataman Yurii ata_kard@ukr.net, ORCID: 0000-0002-6398-1016

Brizhata Iryna brizhata@i.ua, ORCID: 0000-0002-9988-4285

Simonenko Iryna irinasimonenko.532@gmail.com, ORCID: 0000-0002-8406-5682

Сумський державний університет

40001, Ukraine, Sumy, Academichna Str. 9

Ataman Alexander olex0101@gmail.com, ORCID: 0000-0002-1941-740X

Сумський державний університет

40007, Ukraine, Sumy, Sanatorna Str. 31
5. Platonov VN. General theory of training athletes in Olympic sports. Kiev: Olympic sport; 1997. 583 p.

6. Baumert M, Brechtel L, Lock J, Hermsdorf $M$, Wolff $R$, et al. Heart rate variability, blood pressure variability, and baroreflex sensitivity in overtrained athletes. Clin J Sport Med. 2016 Sep;16(5):412-7. doi: 10.1097/01. jsm.0000244610.34594.07.

7. Berge H, Isern C, Berge E. Blood pressure and hypertension in athletes: a systematic review. Br. J. Sports Med. 2015;49 (11): 716-723. doi: 10.1136/bjsports-2014-093976

8. Berge HM, Andersen T, Solberg E, Steine K. High ambulatory blood pressure in male professional football players. Br J Sports Med. 2013 May;47(8):521-5. doi: 10.1136/bjsports-2013092354 .

9. Brizhatyi A, Ataman Y, Brizhataia I, Korzh V, Zharkova $A$, et al. Ventricular repolarization measures in professional and amateur athletes with high normal arterial pressure. Georgian Med News. 2020 Jan;(298):123-128.

10. Haviland M. Yates's correction for continuity and the analysis of $2 \times 2$ contingency tables. Stat Med. 1990 Apr;9(4):363-7; discussion 369-83. doi: 10.1002/sim.4780090403

11. Hedman K, Moneghetti K, Christle J, Bagherzadeh S, Amsallem M, et al. Blood pressure in athletic preparticipation evaluation and the implication for cardiac remodeling. Heart. 2019 Aug:105(16):1223-1230. doi: 10.1136/ heartjnl-2019-314815.

12. Garrett W, Kirkendall J, Kirkendall D. Exercise and Sport Science. USA: Walters Kluwer Health; 2000. 500 p.

13. Grandou C., Wallace L, Impellizzeri F Allen N, Coutts A. Overtraining in Resistance Exercise: An Exploratory Systematic Review and Methodological Appraisal of the Literature. Sports Med. 2020 Apr;50(4):815-828. doi: 10.1007/ s40279-019-01242-2.

14. James G, Gerber L. Measuring arterial blood pressure in humans: Auscultatory and automatic measurement techniques for human biological field studies. Am J Hum Biol. 2018 Jan;30(1) ):421-5. doi: 10.1002/ajhb.23063.

15. Kokubo Y, Kamide K. High-normal blood pressure and the risk of cardiovascular disease. Circ J. 2009 Aug;73(8):1381-5. doi: 10.1253/circj. cj-09-0336.

16. Kreher J, Schwartz J. Overtraining syndrome: a practical guide. Sports Health. 2012 Mar;4(2):128-38. doi: 10.1177/1941738111434406.

17. Pescatello L, Buchner D, Jakicic J, Powell K, Kraus W, et al. Physical Activity to Prevent and Treat Hypertension: A Systematic Review. Med Sci Sports Exerc. 2019 Jun;51(6):1314-1323. doi: 10.1249/MSS.0000000000001943.

18. Stergiou G, Kario K, Kollias A, McManus R, Ohkubo T, et al. Home blood pressure monitoring in the 21st century. J Clin Hypertens (Greenwich). 2018 Jul;20(7):1116-1121. doi: 10.1111/jch.13284

19. Vischer A, Burkard T. Principles of Blood Pressure Measurement - Current Techniques, Office vs Ambulatory Blood Pressure Measurement. Adv Exp Med Biol. 2017;956:85-96. doi: 10.1007/5584_2016_49.

20. Williams B, Mancia G, Spiering W, Agabiti Rosei E, Azizi M, et al. 2018 ESC/ESH Guidelines for the management of arterial hypertension: The Task Force for the management of arterial hypertension of the European Society of Cardiology (ESC) and the European Society of Hypertension (ESH). European Heart Journal. 2018 Sep;39(33):3021-3104. doi: 10.1093/eurheartj/ehy339. 